\title{
Molecular Approaches to Diagnosis of Invasive Aspergillosis; What we Know and What we do not Know
}

\author{
Maryam Moazeni ${ }^{1,2}$, Mojtaba Nabili ${ }^{1,3}$, Sadegh Khodavaisy ${ }^{4,5}$, Hamid Badali ${ }^{1,2 *}$ \\ ${ }^{1}$ Department of Medical Mycology and Parasitology, School of Medicine, Mazandaran University of Medical Sciences, Sari, Iran. \\ ${ }^{2}$ Molecular and Cell Biology Research Centre (MCBRC), Mazandaran University of Medical Sciences, Sari, Iran. \\ ${ }^{3}$ Social Security Organizatin, Golestan, Iran. \\ ${ }^{4}$ Department of Medical Parasitology and Mycology, Kurdistan University of Medical Sciences, Sanandaj, Iran. \\ ${ }^{5}$ Department of Medical Parasitology and Mycology, Tehran University of Medical Sciences, Tehran, Iran.
}

Received: 15 Feb 2013

Revised : 20 Apr 2013

Accepted: 17 Aug 2013

Corresponding Author:

Hamid Badali

Department of Medical Mycology and

Parasitology, School of

Medicine/Molecular and Cell Biology

Research Centre, Mazandaran

University of Medical Sciences, Sari,

Iran.

Phone: +989128413720

E-mail: badalii@yahoo.com

\begin{abstract}
Invasive aspergillosis (IA) is a major complication in immunocompromized patients where can be serious and rapidly fatal. Early diagnosis and appropriate antifungal treatment is important in reducing mortality and morbidity. Despite many efforts to develop detection methods, the diagnosis of IA still remains challenging and current conventional methods are limited for adequate diagnosis. New rapid methods which can detect IA early in the course of disease with high sensitivity and specificity are needed to treat these infections at an early stage. Using molecular methods for the identification of Aspergillus species can be a cost-effective, rapid, discriminatory, and objective approach for delineating Aspergillus species in a clinical microbiology laboratory. PCR techniques for the diagnosis of IA have been studied for more than a decade and are still considered investigational; however, until now PCR is not included in current EORTC/MSG diagnostic criteria.
\end{abstract}

Keywords: Invasive aspergillosis; PCR; Molecular approaches; Real-time PCR

Please cite this article as: Moazeni M, Nabili M, Khodaveisi S, Badali H. Molecular Approaches to Diagnosis of Invasive Aspergillosis; What we Know and What we do not Know. Res Mol Med. 2013; 1 (2): 3-9

\section{Introduction}

Invasive aspergillosis (IA) is a major complication in immunocompromized patients with haematopoietic stem cell or solid organ transplantation, ICU patients, and especially those with prolonged neutropenia which are high-risk populations where IA can be serious and rapidly fatal (1-2). The incidence of IA continues to rise in conjunction with the increasing population of susceptible individual. IA has a high mortality rate of up to $60 \%$ or even higher if the diagnosis is delayed (3). Early diagnosis and early appropriate antifungal treatment is important in reducing mortality and morbidity (4). Despite many efforts to develop detection methods, the diagnosis of IA still remains challenging and current conventional methods are limited for adequate diagnosis (5). Several reasons are responsible for these limitations, such as non-specific and variable clinical symptoms that occur late in the course of disease, considerable delay in turn-around time due to slow growth of the fungus in culture, the time needed for its identification, and especially, a lack of diagnostic methods with sufficient sensitivity and specificity (6). Because of the limitations of the aforementioned diagnostic methods, non-culture methods based on the detection of the molecular biomarkers have been developed. Therefore, it is mandatory to develop and evaluate non-culture based methods for the detection of IA. New rapid methods which can detect IA early in the course of disease with high sensitivity and specificity are needed to treat these infections at an early stage (7). The limitations of antibody detection and the problems of sensitivity and false positive associated with antigen detection have prompted the evaluation of the molecular techniques for the diagnosis of IA (8-9). Using molecular methods for the identification of Aspergillus species can be a costeffective, rapid, discriminatory, and objective approach for delineating Aspergillus species in a 
clinical micro- biology laboratory (10). Thus, Polymerase Chain Reaction (PCR) techniques for the diagnosis of IA have been studied for more than a decade and are still considered investigational; however, until now PCR has not been included in current EORTC/MSG diagnostic criteria. This review focuses on utilization of molecular methods, for diagnosis of invasive aspergillosis.

\section{Molecular approaches}

Owing to the disappointing performance of serologic assays, research has - since the early 1990s - been focused on molecular methods to detect the fungal pathogen early and with high sensitivity. Early studies to evaluate PCR mediated detection of fungi showed significantly improved sensitivity compared with other diagnostic tools at that time, but were performed with different assays and different objectives partly to optimize culture assays $(11,12)$, partly for typing in epidemiologic studies, and often in nonclinical settings $(13,14)$.

The positive benefits of carrying out highly sensitive DNA detection assays should be considered. The first PCR assays detected quantities down to 1-20 pg of genomic DNA from Aspergillus fumigatus in vitro (15). In whole blood between $10-100 \mathrm{fg} / \mathrm{ml}$ of Aspergillus DNA have been reported (16). Klingspor $\mathrm{L}$, et al (18) reported that $30 \mathrm{fg} / \mathrm{ml}$ of Aspergillus DNA were present in sera in contrast, Challier $S$ et al, (17) between $100 \mathrm{fg} / \mathrm{ml}$ to $1 \mathrm{ng} / \mathrm{ml}$. This indicated that a range of different PCR assays (conventional, nested, and real-time based PCRs) have been developed, targeting different gene regions (cytochrome p450, heat shock proteins, 18S, 5.8S, $28 \mathrm{~S}$, and ITS). Furthermore, they include a variety of amplicon detection methods, such as gel electrophoresis, hybridization with specific probes, ELISA, and restriction fragment length polymorphism (RFLP).

These molecular assays provide high potential in terms of sensitivity and specificity, but vary widely in their feasibility and are up to now not standardized. Furthermore, only few standardized assays are now commercially available. This highlights the problems when evaluating publications designed to compare PCR methodologies. Yet, a consensus concerning the type of specimen, the extraction method, and the PCR format and platform has still to be reached. Major issues for Aspergillus-PCR based assays to meet these critical points (18).

\section{Polymerase chain reaction (PCR)}

PCR detection of Aspergillus nucleic acids is increasingly appreciated as being a method of early detection of IA. In contrast with other non-culturebased methods, PCR has the capability of rapid detection and molecular identification of opportunistic moulds besides Aspergillus at the genus level (19). Hundreds of manuscripts have been published dealing with the detection of fungal DNA. However, there has been little standardization in procedures and very few inter-laboratory validation studies.

Which PCR assay that is most suitable is dependent on the demands of the method. PCR assays can be used as (i) diagnostic tools only, (ii) as a means for the early diagnosis of IA, ideally prior to the onset of clinical symptoms, and (iii) as tools to monitor preemptive antifungal therapy. Depending on the purpose of the assay, different technical aspects have to be considered, including the types of samples, the extraction of the nucleic acids, the fungal DNA targets, and the frequency of sampling.

\section{Nested-PCR}

Nested PCR formats have been widely used for Aspergillus spp. in an attempt to optimise analytical sensitivity, but the requirement to open reaction tubes means that there is considerable risk of contamination and the subsequent generation of false-positive results (10).

\section{PCR-ELISA}

In addition, these technologies those are not easily adapted for use in a clinical microbiology laboratory. The major advantages of the PCR-ELISA identification system, compared to conventional phenotypic identification methods, were included as (A) it was rapid (this test could be completed in a single day); (B) it did not require species of Aspergillus to form specialized identifying structures such as conidia; (C) small amounts of DNA target could be detected (picogram quantities); (D) DNA probes could be easily and reproducibly synthesized and stored ready for use; (E) DNA probes were very specific; (F) interpretation of the results were objective (colorimetric, spectrophotometric readout); (G) the detection system has the potential to be easily automated (20).

\section{Real-Time PCR}

Application of real-time PCR technologies allows for rapid and effective post amplification of specific DNA sequences (e.g. ITS1 regions of $18 \mathrm{~S}$ ribosomal subunits) for genus-and species-specific identification of opportunistic fungi. Furthermore, real-time PCR protocols, which are less prone to contamination, along with automated systems for DNA extraction appear to be a significant step towards standardization and improvement of the reliability of the existin PCR assay. Because real-time PCR allows for quantification of the amount of circulating 
Aspergillus DNA, it may also be used as an indirect Parameter of fungal load during monitoring of

treatment with antifungal drugs.

Table 1. Major issues for Aspergillus-PCR based assays.

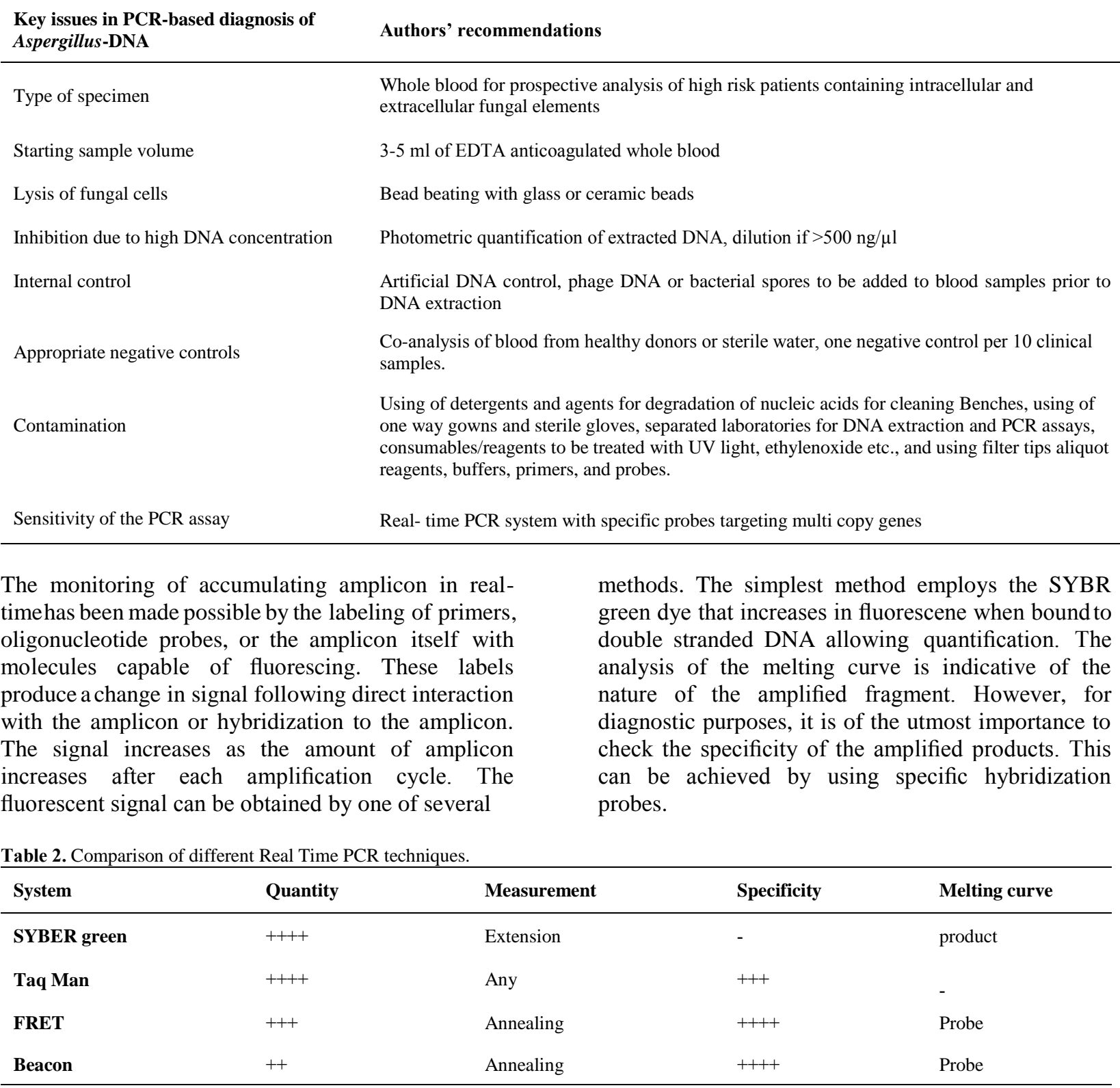

There is a range of chemistries currently in use. One relies upon fluorescence resonance energy transfer (FRET) between fluorogenic probes and has been developed for the LightCycler instrument (Roche Diagnostics). The Applied Biosystems apparatus uses the TaqMan technology based on the 50 nuclease activity of the polymerase to release the two dyes of the fluorogenic probe (21). The choice between these two more popular methods depends on specific demands and/or local opportunities. However, other chemistries are in development such as molecular beacons and scorpion probes $(22,23)$. One of the major disadvantages of SYBR green method is that the SYBR green color nonspecifically binds to all double-stranded DNAs such as primer dimer and other nonspecific bands. Therefore the fluorescent signals derived from the reaction, which is proportional to the amount of double-stranded DNA and the amount of fluorescence increases resulting in decreased specificity and increased false positives. Using this method, Aspergillus species and even other fungal species cannot be distinguished from 
each other and only the type of fungi can be reported. For example, it can only be said whether the fungus is Aspergillus or not. However, the SYBR green method has some advantage as well, such as simple design (only 2 primers are required without any probe), low cost, and the ability to analyze melting curve formed after replication in order to verify the specificity of the reaction.

Table 3. Details of the PCR techniques.

\begin{tabular}{|c|c|c|c|c|c|c|c|}
\hline \multirow{2}{*}{ Study } & \multirow{2}{*}{ Sample type } & \multirow{2}{*}{$\begin{array}{l}\text { Sample } \\
\text { volume }\end{array}$} & \multirow{2}{*}{ Target gene } & \multirow{2}{*}{$\begin{array}{l}\text { Cell wall } \\
\text { disruption }\end{array}$} & \multirow{2}{*}{ PCR method } & \multicolumn{2}{|c|}{ Appropriate controls } \\
\hline & & & & & & Positive & Negative \\
\hline Nabili et al (35) & Whole blood & $3-5 \mathrm{~mL}$ & 18S rRNA & Lyticase & $\begin{array}{l}\text { Real Time/FRET } \\
\text { Probe }\end{array}$ & Serial dilutions & Yes \\
\hline $\begin{array}{l}\text { Hebart et al } \\
(2000)(36)\end{array}$ & Whole blood & $5 \mathrm{~mL}$ & $18 \mathrm{~S}$ rRNA & Zymolyase & PCR-ELISA & Serial dilutions & Yes \\
\hline $\begin{array}{l}\text { Buchheidt et al } \\
(2001)(37)\end{array}$ & $\begin{array}{l}\text { Whole blood } \\
\text { and BAL }\end{array}$ & $3-5 \mathrm{~mL}$ & $18 \mathrm{~S}$ rRNA & Lyticase & Nested PCR & Serial dilutions & Yes \\
\hline $\begin{array}{l}\text { Ferns et al } \\
(2002)(38)\end{array}$ & Whole blood & $2 \mathrm{~mL}$ & mtDNA & Zymolyase & Nested PCR & $\begin{array}{l}\text { Internal control } \\
\text { (ras oncogene) }\end{array}$ & Yes \\
\hline $\begin{array}{l}\text { Raad et al } \\
(2002)(39)\end{array}$ & Whole blood & $700 \mu \mathrm{L}$ & $\begin{array}{l}\text { Alkaline } \\
\text { proteinase } \\
\text { gene mtDNA }\end{array}$ & $\begin{array}{l}\text { SDS, } \\
\text { proteinase }\end{array}$ & Standard PCR & Serial dilutions & Yes \\
\hline $\begin{array}{l}\text { Kawazu et al } \\
(2004)(40)\end{array}$ & Plasma & $200 \mu \mathrm{L}$ & 18S rRNA & $\begin{array}{l}\text { QIAamp } \\
\text { Blood } \\
\text { Mini-Kit }\end{array}$ & $\begin{array}{l}\text { RT-PCR with } \\
\text { TaqMan Probe }\end{array}$ & $\begin{array}{l}\text { Blood } \\
\text { inhibition } \\
\text { control }\end{array}$ & Yes \\
\hline $\begin{array}{l}\text { Lass-Floerl et } \\
\text { al (2004) (41) }\end{array}$ & Whole blood & $10 \mathrm{~mL}$ & 18S rRNA & Zymolyase & PCR-ELISA & $\begin{array}{l}\text { Inhibition } \\
\text { control }\end{array}$ & Yes \\
\hline $\begin{array}{l}\text { Halliday et al } \\
(2006)(42)\end{array}$ & Whole blood & $500 \mu \mathrm{L}$ & 18S rRNA & Lyticase & Nested PCR & Serial dilutions & Yes \\
\hline $\begin{array}{l}\text { Jordanides et al } \\
(2005)(43)\end{array}$ & Whole blood & $10 \mathrm{~mL}$ & $18 \mathrm{~S}$ rRNA & Zymolyase & $\begin{array}{l}\text { RT-PCR with } \\
\text { FRET Probe }\end{array}$ & Serial dilutions & Yes \\
\hline $\begin{array}{l}\text { El Mahallawi et } \\
\text { al (2006) (44) }\end{array}$ & Serum & - & $18 \mathrm{~S}$ rRNA & Lyticase & Standard PCR & Serial dilutions & Yes \\
\hline $\begin{array}{l}\text { Cesaro et al } \\
(2008)(45)\end{array}$ & Whole blood & $3 \mathrm{~mL}$ & 18S rRNA & Zymolyase & $\begin{array}{l}\text { RT-PCR with } \\
\text { FRET Probe }\end{array}$ & Serial dilutions & Yes \\
\hline
\end{tabular}

In the TaqMan method, a reporter is placed at the $5^{\prime}$ head and Quencher at the 3' head and due to having a probe has higher specificity than the SYBR green method. Each other unless for each species, a specific probe can be designed which requires a high cost. On the other hand, the FRET method is designed with two probes with different fluorescent dyes, the probes are quite specifically bounded to the desiredDNA. The design of these probes is so that in cases of differences in even one nucleotide, it does not bind to the DNA. As in this method the probes are not hydrolyzed, the analysis of the melting curve after replication is possible and considering the melting temperature of DNA, which is a specific parameter of this molecule and depends on the DNA structure and factors such as length and number of nucleotides, the probe concentration, the environment's salt concentration and the percentage of GC, Aspergillus species can be differentiated from each other. Additionally, the ability of the real-time PCR assay to simultaneously quantify the fungal DNA load in a variety of clinical specimens makes its clinical usefulness probable helping establish disease severity, monitor antifungal therapy effectiveness and estimate disease advancement; even though, these advantages has to be finally determined in future prospective clinical studies.

Post amplification analysis

Post-amplification detection techniques provide genus or species specific data but may also increase sensitivity and specificity $(24,25)$. Real-time detection techniques (eg, TaqMan, LightCycler, molecular beacons) are automated, rapid, and reproducible, thus facilitating comparisons between studies. Southern blotting has had a valuable role in 
the evolution of PCR as a diagnostic modality, but is unlikely to have any substantial future role in routine clinical assays. Single-strand conformational polymorphism, $(26,27)$ restriction fragment length polymorphism digest pattern, (28) Line Probes, (29) fragment size deter- mination (30), DNA sequence analysis (31-33) and PCR-ELISA may have a limited role in specific instances, such as the identification of laboratory isolates (34). Conclusion: Fungal diagnostics has increased dramatically with the introduction of molecular tools, in particular that of PCR. In recent years, many papers related to improved methods and techniques have been published in order to progress or optimize methods and to conquer or decrease methodological drawbacks, confirming the increased interest in the emerging clinical problem of detecting invasive aspergillosis sensitively and specifically. In addition the use of PCR assays for the diagnosis of IA in patients, this extremely sensitive technology can also be performed to monitor patients at risk to develop IA. These new non culture based diagnostic assays are suitable as simple and rapid screening tests with high sensitivities and quick turnaround times. Thus, they might help to reduce empirical antifungal therapy and might be helpful tools for early beginning and monitoring of antifungal therapy. However, lack of standardization of PCR technique is still one of the factors that EORTC/MSG has not been included this technique in an article published in 2008 for the diagnosis of IA (5). In order to solve this problem in 2006, the group consists of 24 centers under the name 'EAPCRI' (European Aspergillus PCR Initiative) ISHAM was created. They began to establish a standard for the diagnosis of AspergillusPCR. The ultimate goal of reaching a general consensus for DNA extraction and PCR amplification (46). Future prospective studies evaluating the potential benefits of early therapy based on real-time PCR in patients at high risk for IA infections are needed. To be able to validate Aspergillus PCR, we need to perform multi-center studies in order to include enough patients with proven and probable infection according to the EORTC/MSG criteria. So the combination of the different diagnostic assays may be an encouraging approach in some cases. In this manner, test sensitivity might be increased and the false-positive results might be decreased. Particularly, the combination of antigenemia and molecular assays is attractive. Alam et al. reported that sensitivities were $88 \%$ for Candida semi-nested PCR, $47 \%$ for BG, $41 \%$ for Candida mannan and $47 \%$ for antimannan antibodies in pediatric and adult patients with candidemia (47). When the tests were combined, the sensitivities reached $75 \%$ in Candida mannan and antimannan combination, 56\% in
Candida mannan and $\mathrm{BG}$ combination and $88 \%$ in combination of mannan, BG and Candida DNA. White et al. have recommended the combination of PCR and antigenemia assays in the management of high-risk patients (48). Nabili and shokohi et al. evaluated the performance of Real Time PCR and GM antigenemia tests from blood in the diagnosis of invasive aspergillosis and they obtained the best performance with a combination of tests (35). Thus, it has been reported that combination could help to increase sensitivity and help eliminate false-positive tests.

\section{References}

1. Segal BH, Walsh TJ. Current approaches to diagnosis and treatment of invasive aspergillosis. Am J Respir Crit Care Med. 2006; 173: 707-17. PMID: 16387806

2. Patterson TF. Advances and challenges in management of invasive mycoses. Lancet. 2005; 366: 1013-25. PMID: 16168784

3. Von Eiff M, Roos N, Schulten M, Hesse M, Zuhlsdorf M, van de Loo J. Pulmonary aspergillosis: early diagnosis improves survival. Respiration. 1995; 62: 341-7. PMID: 8552866

4. Buchheidt D, Hummel M. Aspergillus polymerase chain reaction (PCR) diagnosis. Med Mycol S. 2005; 43, 139-45. PMID: 16110806

5. De Pauw B, Walsh TJ, Donnelly JP, Stevens DA, Edwards JE, Calandra $\mathrm{T}$, et al. Revised definitions of invasive fungal disease from the European Organization for Research and Treatment of Cancer/Invasive Fungal Infections Cooperative Group and the National Institute of Allergy and Infectious Diseases Mycoses Study Group (EORTC/MSG) Consensus Group. Clin Infect Dis. 2008; 46: 1813-21. PMID: 18462102

6. Maertens JA, Marr KA, editors. Diagnosis of fungal infections. CRC Press; 2007 Aug 29.

7. Lena K, Juergen L. Aspergillus PCR formidable challenges and progress. Med Mycol. 2009; 1: 241-7. PMID: 19253138

8. Alexander BD. Diagnosis of fungal infection: new technologies for the mycology laboratory. Transpl Infect Dis. 2002; 4: (Suppl 3), 32-37. PMID: 12486790

9. Kawazu M, Kanda Y, Goyama S, Takeshita M, Nannya Y, Niino M, et al. Rapid diagnosis of invasive pulmonary aspergillosis by quantitative polymerase chain reaction using bronchial lavage fluid. Am J Hematol. 2003; 72: 27- 30. PMID: 12508264

10. Hope WW, Walsh TJ, Denning DW. Laboratory diagnosis of invasive aspergillosis. Lancet Infect Dis. 2005; 5: 609-22. PMID: 16183515

11. Aufauvre-Brown A, Cohen J, Holden DW. Use of randomly amplified polymorphic DNA markers to distinguish isolates of Aspergillus fumigatus. J Clin Microbiol. 1992; 30: 2991-3. PMID: 1360475

12. Van Belkum A, Quint WG, De Pauw BE, Melchers WJ, Meis JF. Typing of Aspergillus species and Aspergillus fumigatus isolates by interrepeat polymerase chain reaction. J Clin Microbiol. 1993; 31: 2502-505. PMID: 8408576 
13. BirchM, Nolard N, Shankland GS, Denning DW. DNA typing of epidemiologically-related isolates of Aspergillus fumigatus. Epidemiol Infect. 1995; 114: 161-8. PMID: 7867735

14. Verweij PE, Meis JF, Sarfati J, et al. Genotypic characterization of sequential Aspergillus fumigatus isolates from patients with cystic fibrosis. J Clin Microbiol. 1996; 34: 2595-59. PMID: 8880528

15. Reddy LV, Kumar A, Kurup VP. Specific amplification of Aspergillus fumigates. DNA by polymerase chain reaction. Mol Cell Probes. 1993; 7: 121-6. PMID: 8321251

16. Loeffler JH, Hebart H, Brauchle U, Schumacher U, Einsele H. Comparison between plasma and whole blood specimens for detection of Aspergillus DNA by PCR. J Clin Microbiol. 2000; 38: 3830-3. PMID: 11015412

17. Challier S, Boyer S, Abachin E, Berche P. Development of a serum-based Taqman real-time PCR assay for diagnosis of invasive aspergillosis. J Clin Microbiol. 2004; 42: 844-6. PMID: 14766869

18. Klingspor L, Loefflers J. Aspergillus PCR formidable challenges and progress. Med Mycol. 2009; 47: 241-7. PMID: 19253138

19. Chen SC, Halliday CL, Meyer W. Review of nucleic acidbased diagnostic tests for systemic mycoses with an emphasis on polymerase chain reaction-based assays. Med Mycol. 2002; 40: 333-57. PMID: 12230214

20. Hinrikson HP, Hurst SF, Aguirre L, Morrison CJ. Molecular methods for the identification of Aspergillus species. Med Mycol. 2005; 43: 129-37. PMID: 16110805

21. Bretagne S, Costa JM. Towards a molecular diagnosis of invasive aspergillosis and disseminated candidosis. FEMS Immunol Med Microbiol. 2005; 45: 361-8. PMID: 16054349

22. Vet JA, Majithia AR, Marras SA, Tyagi S, Dube S, Poiesz BJ, Kramer FR. Multiplex detection of four pathogenic retroviruses using molecular beacons. Proc Natl Acad Sci USA. 1999; 9: 6394 9. PMID: 10339598

23. Saha BK, Tian B, Bucy RP. Quantitation of HIV-1 by realtime PCR with a unique fluorogenic probe. J Virol Methods. 2001; 93: 33-42. PMID: 11311341

24. Melchers WJ, Verweij PE, van den Hurk P, et al. General primer- mediated PCR for detection of Aspergillus species. J Clin Microbiol. 1994; 32: 1710-17. PMID: 7929762

25. Spreadbury C, Holden D, Aufauvre-Brown A, Bainbridge B, Cohen J. Detection of Aspergillus fumigatus by polymerase chain reaction. J Clin Microbiol. 1993; 31: 615-21. PMID: 8458955

26. Walsh TJ, Francesconi A, Kasai M, Chanock SJ. PCR and single strand conformational polymorphism for recognition of medically important opportunistic fungi. J Clin Microbiol. 1995; 33: 3216-20. PMID: 8586705

27. Rath PM, Ansorg R. Identification of medically important Aspergillus species by single strand conformational polymorphism (SSCP) of the PCR-amplified intergenic spacer region. Mycoses. 2000; 43: 381-6. PMID: 11204354

28. Hopfer RL, Walden P, Setterquist S, Highsmith WE. Detection and differentiation of fungi in clinical specimens using polymerase chain reaction (PCR) amplification and restriction enzyme analysis. J Med Vet Mycol. 1993; 31: 65-75. PMID: 8097766

29. Martin C, Roberts D, van Der Weide M, et al. Development of a PCR based line probe assay for identification of fungal pathogens. J Clin Microbiol. 2000; 38: 3735-42. PMID: 11015393

30. Turenne CY, Sanche SE, Hoban DJ, Karlowsky JA, Kabani AM. Rapid identification of fungi by using the ITS2 genetic region and an automated fluorescent capillary electrophoresis system. J Clin Microbiol. 1999; 37: 1846-51. PMID: 10325335

31. Costa C, Vidaud D, Olivi M, Bart-Delabesse E, Vidaud M, Bret- agne S. Development of two real-time quantitative TaqMan PCR assays to detect circulating Aspergillus fumigatus DNA in serum. J Microbiol Methods. 2001; 44: 263-9. PMID: 1124004

32. Henry T, Iwen P, Hinrichs H. Identification of Aspergillus species using internal transcribed spacer regions 1 and 2. J Clin Microbiol. 2000; 38: 1510-15. PMID: 10747135

33. Pryce TM, Pallidino S, Kay D, Coombs GW. Rapid identification of fungi by sequencing the ITS1 and ITS2 regions using an automated capillary electrophoresis system. Med Mycol. 2003; 41: 369-81. PMID: 14653513

34. De Aguirre L, Hurst SF, Choi JS, Shin JH, Hinrikson HP, Morrison CJ.Rapid differentiation of Aspergillus species from other medically important opportunistic molds and yeasts by PCRenzyme immunoassay. J Clin Microbiol. 2004; 42: 3495-504. PMID: 15297489

35. Nabili M, Shokohi T, Janbabaie G, Hashemi-Soteh MB, AliMoghaddam K, Aghili SR. Detection of invasive aspergillosis in bone marrow transplant recipients using real-time PCR. J Global Infect Dis. 2013; 5: 68-75. PMID: 23853434

36. Hebart H, Loffler J, Reitze H, Engel A, Schumacher U, Klingebiel $\mathrm{T}$, et al. Prospective screening by a panfungal polymerase chain reaction assay in patients at risk for fungal infections: implications for the management of febrile neutropenia. Br J Haematol. 2000; 111: 635-40. PMID: 11122112

37. Buchheidt D, Hummel M, Schleiermacher D et al. Prospective clinical evaluation of a LightCycler-mediated polymerase chain reaction assay, a nested-PCR assay and a galactomannan enzymelinked immunosorbent assay for detection of invasive aspergillosis in neutropenic cancer patients and haematological stem cell transplant recipients. Br J Haematol. 2004; 125: 196-202. PMID: 15059142

38. Ferns RB, Fletcher H, Bradley S, Mackinnon S, Hunt C, Tedder RS. The prospective evaluation of a nested polymerase chain reaction assay for the early detection of Aspergillus infection in patients with leukaemia or undergoing allograft treatment. Br J Haematol. 2002; 119: 720-25. PMID: 12437651

39. Raad I, Hanna H, Sumoza D, Albitar M. Polymerase Chain Reaction on Blood for the Diagnosis of Invasive Pulmonary Aspergillosis in Cancer Patients. Cancer. 2002; 94: 1032-6. PMID: 11920473

40. Kawazu M, Kanda Y, Nannya Y, et al. Prospective comparison of the diagnostic potential of real-time PCR, double-sandwich enzyme-linked immunosorbent assay for galactomannan, and a $(1 \rightarrow 3)-\beta$-d-glucan test in weekly screening for invasive aspergillosis in patients with hematological disorders. J Clin Microbiol. 2004; 42: 2733-41. PMID: 15184460 
41. Lass-Flörl C, Gunsilius E, Gastl G, Bonatti H, Freund MC, Gschwendtner A, et al. Diagnosing invasive aspergillosis during antifungal therapy by PCR analysis of blood samples. J Clin Microbiol. 2004; 42: 4154-57. PMID: 15365004

42. Halliday C, Hoile R, Sorrell T, et al. Role of prospective screening of blood for invasive aspergillosis by polymerase chain reaction in febrile neutropenic recipients of haematopoietic stem cell transplants and patients with acute leukaemia. Br J Haematol. 2006; 132: 478-86. PMID: 16412020

43. Jordanides NE, Allan EK, McLintock LA, Copland M, Devaney M, Stewart K, et al. A prospective study of real-time panfungal PCR for the early diagnosis of invasive fungal infection in haemato-oncology patients. Bone Marrow Transplant. 2005; 35: 389-95. PMID: 15640828

44. El-Mahallawy HA, Shaker HH, Ali Helmy H, Mostafa T, Razak Abo-Sedah A. Evaluation of pan-fungal PCR assay and Aspergillus antigen detection in the diagnosis of invasive fungal infections in high risk paediatric cancer patients. Med Mycol. 2006; 44: 733-7. PMID: 17127630
45. Cesaro S, Stenghele C, Calore E, et al. Assessment of the lightcycler PCR assay for diagnosis of invasive aspergillosis in paediatric patients with onco-haematological diseases. Mycoses. 2008; 51: 479-504. PMID: 18331444

46. Klingspor L, Loeffler J. Aspergillus PCR formidable challenges and progress. Med Mycol. 2009; 47: 241-7. PMID: 19253138

47. Alam FF, Mustafa AS, Khan ZU. Comparative evaluation of $(1,3)$-b-d-glucan, mannan and anti-mannan antibodies, and Candida species-specific snPCR in patients with candidemia. BMC Infect. Dis. 2007; 7: 103-112. PMID: 17784947

48. White PL, Barton R, Guiver M, Linton CJ, Wilson S, Smith M. Aconsensus on fungal polymerase chain reaction diagnosis? a United Kingdom-Ireland evaluation of polymerase chain reaction methods for detection of systemic fungal infections. J Mol Diagn. 2006; 8: 376-84. PMID: 16825512 